\section{Kropelnytska 5., Hryhoriv 0.}

\title{
RESEARCH OF INSTITUTIONAL ASPECTS OF THE PROJECT FINANCING OF SOCIO-ECONOMIC DEVELOPMENT OF THE REGION
}

Об'єктом дослідження є інституиійні аспекти проектного фінансування соціально-економічного розвитку регіону. Одним з найбільш проблемних місць є непрозора й недосконала система застосування проектного підходу до його фінансового забезпечення.

У дослідженні подано узагальнене й інтерпретоване визначення проектного фінансування соціальноекономічного розвитку регіону як інноваційного механізму фінансового забезпечення виконання стратегічних завдань соціально-економічного розвитку регіону на базі проектного підходу. Проведено аналіз проблемних аспектів інституціоналізацї державної фінансової підтримки розвитку регіонів на базі проектного підходу:

- кошти Державного фонду регіонального розвитку (ДФРР);

- субвенція на розвиток інфраструктури об'єднаних територіальних громад (ОТГ);

- кошти державного бюджету України, отримані від Європейського Союзу.

Застосовано інституційний підхід для розгляду механізмів взаємодї̈ та зв'язків суб'єктів суспільних відносин, оцінки ї поведінки у виконанні норм розподілу та використання коштів на проектне фінансування. Визначено ключові спільні та відмінні інституційні аспекти проектного фінансування сочіальноекономічного розвитку регіонального рівня. Встановлено основні проблемні аспекти задля удосконалення інституційних засад проектного фінансування соціально-економічного розвитку регіону.

У роботі обгрунтовано, що невідповідність проектів завданням регіональних стратегій розвитку, технічним завданням до планів з їх реалізачї, а також лобіювання не розвиткових проектів, а «проектів підтримки поточної діяльності» не сприяють розвитку територій.

Результати дослідження рекомендовано до використання у практичній діяльності представникам законодавчих та виконавчих органів влади, які приймають рішення щодо застосування інструментів проектного фінансування сочіально-економічного розвитку регіону. Запропоновано експертним комісіям з відбору проектів регіонального розвитку, робочим групам зі стратегічного планування розвитку територій врахувати виявлені позитивні та негативні чинники для удосконалення механізмів державної фінансової підтримки розвиткових проектів на рівні регіонів.

Ключові слова: соціально-економічний розвиток регіону, проектне фінансування, інституційні аспекти, проектний підхід, державна підтримка, секторальна бюджетна підтримка.

Received date: 27.11.2019

Accepted date: 16.12.2019

Published date: 28.02.2020
Copyright (c) 2020, Kropelnytska S., Hryhoriv O. This is an open access article under the CC BY license (http://creativecommons.org/licenses/by/4.0)

\section{Introduction}

The financial and institutional support of the socioeconomic development of the regions is one of the important tools of state regional policy. The availability of funds allocated for the development of territories directly affects the possibility of its application, and effective mechanisms and approaches affect the ability of regions to use these funds. The reform of decentralization of power led to a shift in emphasis in responsibility for the development of regions from the state and regional and district administrations to the united territorial communities (UTC) during the allocation of funds. Mobilization of funds for local needs, including through the project approach, has become the main task of local governments [1, 2]. Moreover, transparency and perfect institutionalization [3] of project financ- ing $[4,5]$ are significant factors contributing to finding funds to finance needs and their successful use. Studies of the topics of budget support in comparison with project financing are interesting [6, 7]. Also noteworthy is the issue of introducing a project approach in managing the regional economy [8] and regional financial integration, financing economic development [9].

Despite the relevance of the topics of financial support and management of the socio-economic development of the regions, the institutional foundations of project financing in the complex have been studied extensively. Therefore, the object of this research is the institutional aspects of project financing of the socio-economic development of the region. And the aim of research is analysis of the institutional foundations of project financing of the socio-economic development of the region and 
generalize the problematic aspects in order to improve its implementation.

\section{Methods of research}

During the research, general scientific and special methods are used:

- analysis and synthesis - in order to study the nature of project financing of the socio-economic development of the region, the status and trends of financing of regional development projects in Ukraine;

- comparisons - for a comparative analysis of the sources of state support for regional development projects;

- institutional approach - for review and assess the behavior of subjects of public relations in fulfilling the norms of distribution and use of funds for project financing; - generalization of the results - in the formation of conclusions.

\section{Research results and discussion}

The socio-economic development of the region (SEDR) is closely connected not only with the availability of resources, but also with a certain combination of them. In the absence of one of them, development is impossible, even if other resources are in abundance. The so-called strategic resources include (Fig. 1): physical capital; human capital; social capital; market infrastructure; financial resources. Let's note that the search for funds is most often perceived by most local governments as allocation of funds from the state budget, but not as a source of self-financing [10].

Project financing of socio-economic development is gradually being integrated as one of the effective tools for sustainable growth of communities and territories, given its relevance in the context of decentralization reforms.

In the study, to use the actual, generalized and interpreted definitions of project financing of the socio-economic development of the region: the innovative financial mechanism (including investment, credit, grant, etc.). Ensuring the fulfillment of the strategic tasks of the socio-economic development of the region based on the project approach.

It should be noted that as a result of financial decentralization, new resources have appeared that communities and regions as a whole can receive precisely through the project approach to their attraction and use.

So, new or relatively new sources are financing from the State Regional Development Fund (SRDF), a subvention for the development of the UTC infrastructure and funds from the state budget of Ukraine received from the European Union (Fig. 2). Let's briefly consider the main trends in their use and compare the problem points.

SRDF is one of the most important financial instruments to support socio-economic development, created back in 2012. Its funds should be allocated for the implementation of investment programs and regional development projects, which correspond to the priorities defined in the State Strategy for Regional Development, regional de-

velopment strategies and action plans for their implementation. At the same time, the actual support of the regions within the framework of the SRDF began only in 2015 and not quite in accordance with the stipulated directions and priorities [13].

In 2019 , it is possible to observe a significant increase in the volume of SRDF financing, namely, to $308.0 \mathrm{mil}-$ lion USD versus 240.0 million USD in 2018, 140.0 million USD in 2017 and 120.0 million USD in 2016 (in 2015 this figure was 116.0 million USD), i. e. more than twice. 300.0 million USD is provided for 2020 [12].

20.0 million USD have already been allocated in the State budget for distribution through the State Regional Development Fund. Successful projects should be aimed at implementing the State Strategy for Regional Development until 2020 and relevant regional development strategies.

Instead, let's have a situation (Fig. 3).

For the period 2015-2017 all projects implemented from the SRDF funds for the implementation of action plans for the implementation of regional development strategies were actually aimed at achieving only $17 \%$ of the total number of strategic objectives. Considering the fact that the monitoring period for SRDF projects coincided with the validity period of most action plans for the implementation of regional development strategies (2015-2017), it is possible to state an obvious mismatch between the planned regions and the actual changes achieved.

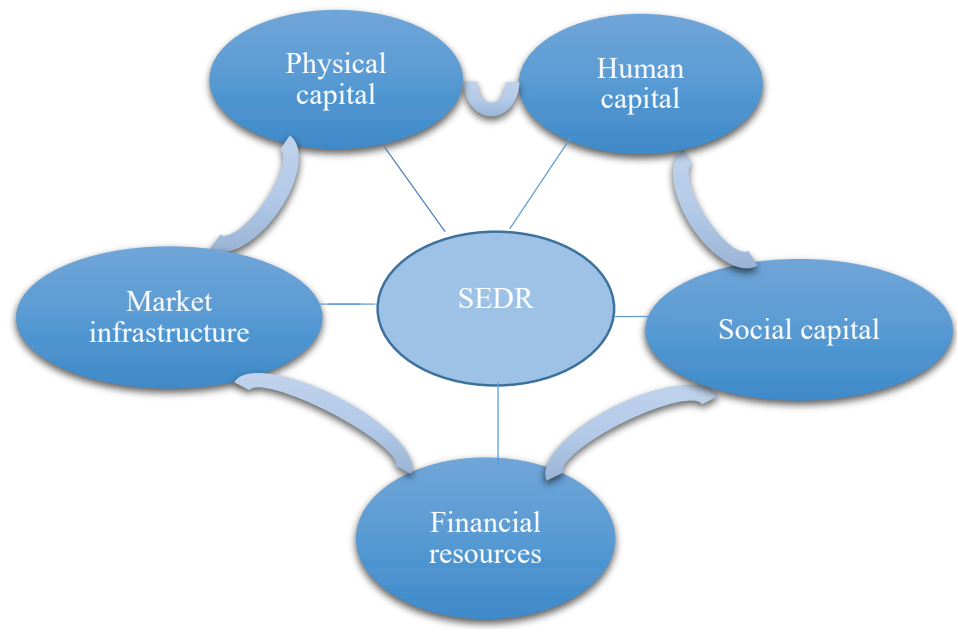

Fig. 1. The relationship of the category of socio-economic development of the region (5EDR) with strategic resources to ensure it (developed on the basis of [10])

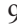
8 7 6 5 4 4 3 2 1 0 2015

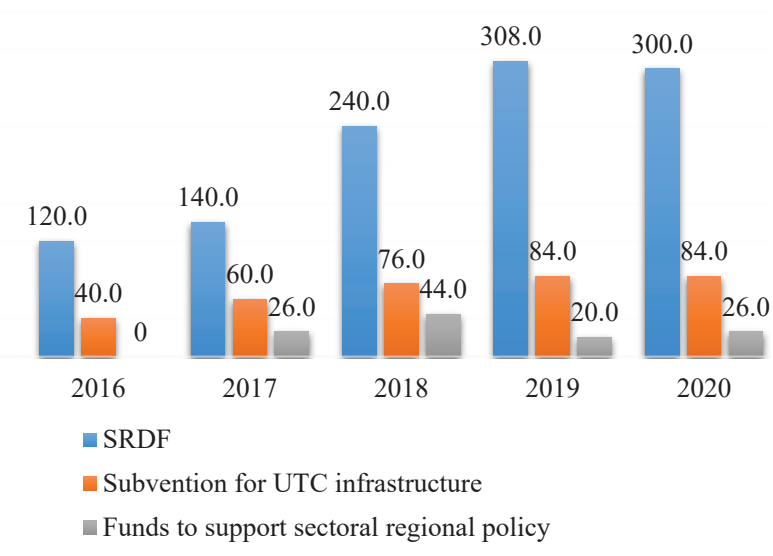

- Funds to support sectoral regional policy

Fig. 2. State financial support for the socio-economic development of the regions on the basis of the project approach, million USD (compiled on the basis of $[11,12]$ ) 


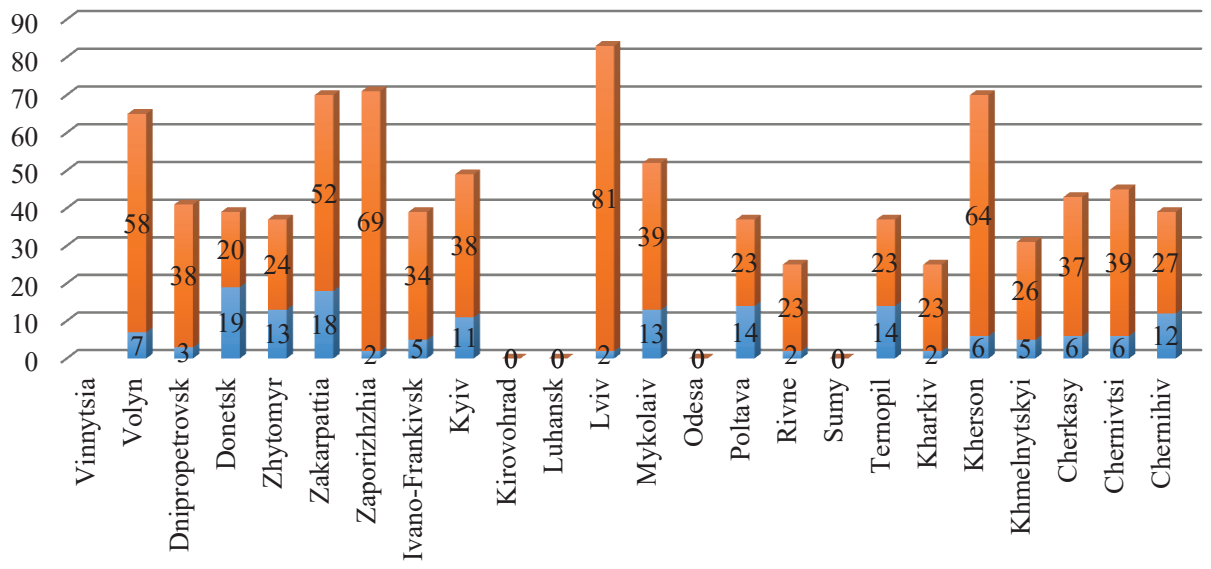

- The objective of the regional strategy in which there are no SRDF projects, items

- The objective of the regional strategy in which the projects were submitted, items

Fig. 3. Conformity of projects with the objective of regional development strategies [14]

For projects which implementation was completed in 2018, an analysis of compliance with the objectives of the strategies was not carried out, since the validity of the implementation plans for 2018-2020. It has not yet been completed, and in some areas they have not been approved.

$98.5 \%$ of the total number of SRDF projects was presented as projects in the action plan for the implementation of the regional development strategy. The territory of influence of most projects ( $63.4 \%$ of the total) does not exceed the size of one community [14]. This indicates that the projects do not have regional significance, affect only local development. In most cases, this influence is doubtful. In addition, $35.4 \%$ of project descriptions generally do not contain indicators (indicators) by which to evaluate the socio-economic effect of the project.

Co-financing of such projects from local budgets should be at least $10 \%$. To implement this initiative, amendments to the Budget Code and related by-laws have already been adopted.

To ensure the transparency of the process, since 2020 it has already been planned:

- create an online platform for the submission, processing and voting of projects;

- develop a map covering all stages in terms of se-

lected areas, projects, directions, budgets and the like;

- conducting public discussions and information campaigns [15].

High-quality selection of projects by proper implementation can be an incentive to attract citizens to solve local problems.

Problematic aspects of the institutionalization of project financing SEDR are characteristic of another tool, which is based on the project approach. On the subvention for the UTC infrastructure, it can be noted that this financial support tool, based on the development of infrastructure projects, is a direct consequence of financial decentralization. Subjects of regional development - united territorial communities - can use it again. It stands out exclusively from UTC since 2016, when the first united territorial communities began to fully function. The funds are provided for by the law «On the voluntary association of territorial communities» [16]. For four years, 260.0 million USD were allocated. The subvention is aimed specifically at sup- porting rural areas - the size of the subvention takes into account the area of the community and the number of rural population.

Subvention funds should be used for capital expenditures, that is, expenses for the UTC development, and not for consumption expenditures. The subvention covers such areas as: administrative services, construction and repair of roads, reconstruction of buildings, purchase of vehicles, in particular for transporting children to school, and the like. Financing the development of the UTC infrastructure from the state budget is subject to the development by local authorities of targeted projects.

For 4 years (2016-2019), the amount of funds allocated in the state budget for the support and development of the UTC infrastructure has grown 2.1 times. In 2019, the volume of infrastructure subvention for UTC is 84.0 million USD. At first glance, this is a tiny amount for the trillion state budget. But in 2018, the share of infrastructure subvention in the total volume of transfers from the state budget to UTC budgets reached almost $10 \%$.

However, from year to year, for each individual UTC, the amount of the subvention is reduced. The reason is that new UTCs are being created at a faster pace than in the state budget they are increasing the amount of infrastructure subvention. So, if in 2016, 40.0 million USD of the infrastructure subvention was divided into 159 UTCs, then in 2019, 84.0 million USD were divided into 810 UTCs, and already in 2020, the same amount for the previous year was provided for 1005 UTCs. Thus, the best opportunities to improve their infrastructure for state budget funds should be those UTCs that were created earlier.

It is worth noting that in 2018, the communities could not use all the funds that were allocated for the infrastructure subvention. $2 \%$ remained undeveloped. This was mainly due to the following problems:

- technical nature (delaying the development of design estimates, a lengthy process of concluding contracts with contractors, the need for additional work, etc.); - poor management of local authorities to redistribute the savings to other facilities. At the same time, there is a positive reduction in the share of unused funds, because in 2016 it amounted to $5.6 \%$ of the total infrastructure subvention. 
Other gaps in the mechanism for the distribution and use of the infrastructural subventions of UTC are:

- disproportionate annual increase in the number of

UTC and funds allocated from the state budget for it; - not taking into account the real needs of the UTC, but focusing only on the legally established distribution requirements on the basis of the UTC area and the number of rural population;

- lack of multiplication of the effect of the received funds of the subvention to attract private investors;

- emphasis on projects supporting social infrastructure, rather than developing projects for the future.

The third tool is sectoral budget support, consisting of payments (tranches) of the European Commission. The first («fixed») tranche is listed under the condition that the national authorities have met certain preliminary assessment conditions, and the receipt of the next («variable») tranche depends on the fulfillment of the success criteria of the support program. The financial resources provided by the EU as part of sectoral budget support programs are inherently a grant. The mechanism of sectoral budget support is new for Ukraine and was first introduced in 2008 in the framework of the European Neighborhood and Partnership Instrument (ENPI) [17].

In 2014, the Government of Ukraine and the European Commission concluded an Agreement on the financing of the Sectoral Policy Support Program - Support to the regional policy of Ukraine (hereinafter - the Agreement) [18].

Regional development projects are an engine for the development of the economy of both individual territories and the state as a whole. In accordance with the legislation, such projects are:

- complexes of interrelated activities to address in-

dividual problems of regional development;

- documents drawn up in the manner prescribed by law, which determine the general actions of project participants and the resources necessary to achieve the project objectives within the established time frames [19].

In 2017, on the territory of Ukraine, as part of the implementation of the mentioned Agreement, the first competitive selection was announced using a new financial instrument to support the implementation of development projects. It is possible to talk about the state budget funds received from the European Union - sectoral budget support of the EU. So, Fig. 4 shows the results of the first competitive selection: the winners were selected 70 projects from different regions of Ukraine, the total funding provided for 2018 [21] amounted to 24.82 million USD.

At this stage, the implementation of the winning projects of the first competition continues and the Ministry of Development of Communities and Territories of Ukraine is preparing for the announcement of the second competition. Therefore, it is important to take into account features and problematic aspects based on the results of the participation of previous applicants and performers, including the Vasyl Stefanyk Precarpathian National University (IvanoFrankivsk, Ukraine). On the territory of the Ivano-Frankivsk region, the university is implementing the project «Creation of a Project and Educational Center for the development of innovations and investments in the region», thanks to which the Agents of changes Center has been operating for two years. The center team provides consulting and educational support for project management. The authors of the study are the chief and financial managers, respectively.

Directions of regional development projects that can be implemented at the expense of the state budget received from the European Union should clearly correspond to two areas: the state strategy for regional development until 2020 and regional development programs. This is the main similarity of all the SEDR project financing tools that are considered in this paper. This and other institutional aspects of SEDR financing based on the project approach are summarized in Table 1.

Given the established aspects, it can be summarized that the distribution of funds and their actual use to ensure SEDR through financing regional development projects and UTC infrastructure development projects have a sufficient number of common features and elements. This indicates an increasingly high-quality unification of the procedures for project financing of SEDR and regional development as a whole and the construction of an integrated and transparent system of its institutional support.

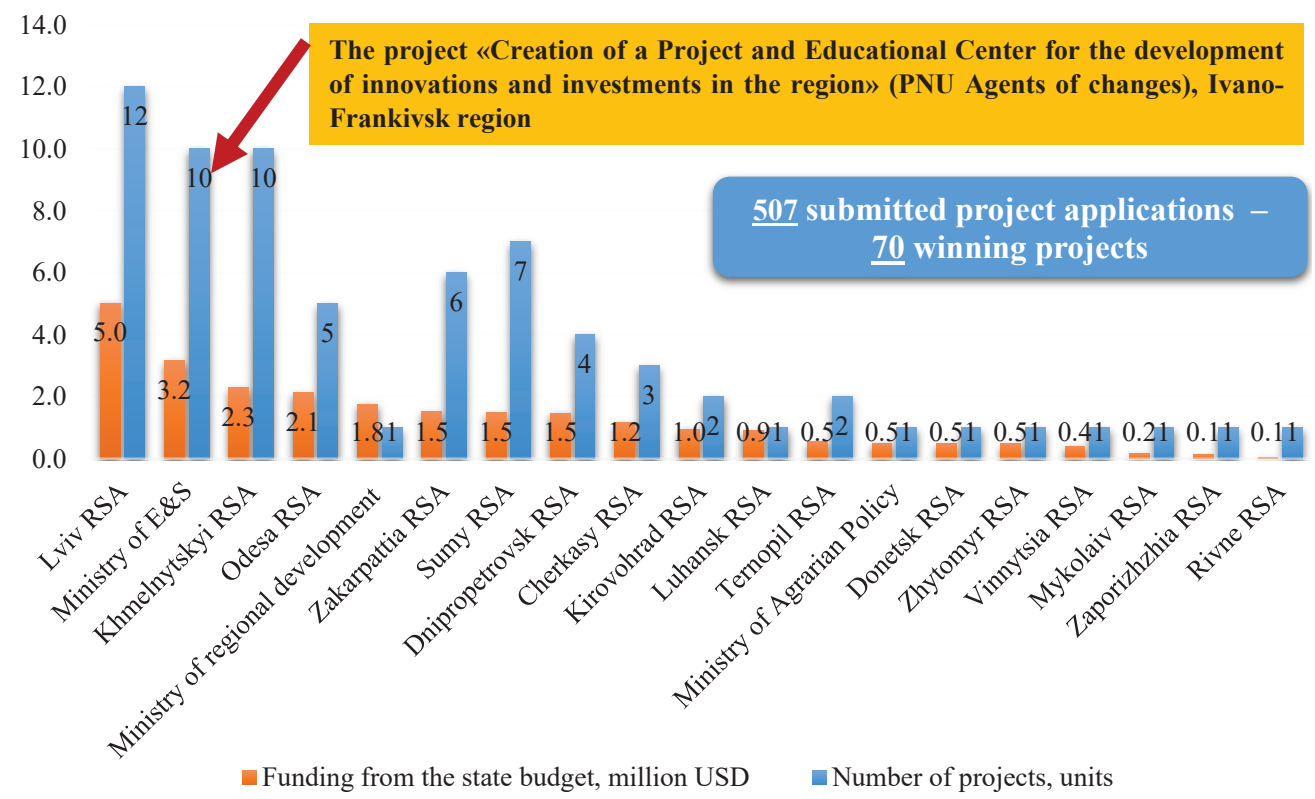

Fig. 4. Distribution of projects winning the first competitive selection within the framework of the EU sectoral budget support program [20] 
Key general and distinctive institutional aspects of project financing of socio-economic development of regions (5EDR)

\begin{tabular}{|c|c|c|c|}
\hline Institutional aspects of SEDR project finance & SRDF & $\begin{array}{l}\text { UTC infrastructure } \\
\text { subvention }\end{array}$ & EU sectoral budget support funds \\
\hline Legislative and/or other regulatory document & + & + & + \\
\hline Ргојесt арргоасh & + & + & + \\
\hline Competitive selection procedure & + & $+/-$ & + \\
\hline $\begin{array}{l}\text { Compliance with the goals and objectives of regional develop- } \\
\text { ment strategies (actual) }\end{array}$ & $+/-$ & $+/-$ & $+/-$ \\
\hline Quota allocation of funds & + & + & $+/-$ (It has not been established in the first contest) \\
\hline $\begin{array}{l}\text { Mandatory requirements for co-financing of the project, provides } \\
\text { an advantage in the selection }\end{array}$ & + & - & $+/-$ \\
\hline Online platform for submitting, processing and voting projects & + & - & $+/-$ (It has not been established in the first contest) \\
\hline
\end{tabular}

\section{Conclusions}

It is revealed that in the context of decentralization reforms, project financing of socio-economic development becomes especially important. Gradually, it is successfully integrating as one of the effective tools for sustainable growth of communities and territories. The key financial instruments of state support for SEDR have been identified, which can be applied through the project approach:

- funds of the State Regional Development Fund (SRDF);

- subvention for the development of UTC infrastructure;

- funds of the state budget of Ukraine received from

the European Union.

As a result, both positive and negative aspects of their institutionalization are identified. In particular, the number of regional administrations is gradually increasing, transparent competition procedures are being applied to project projects, regional administrations and UTCs are more flexible than at the national level, they identify priorities for providing financing.

It has been substantiated that the negative institutional aspects of the SEDR project financing are much greater and they are characteristic of all the sources of financing indicated above. Typically, the scale of socioeconomic development projects should cover at least half of the region, but very often the SEDR project financing tool is used to develop one community. The provision of financing for the mentioned financial instruments is carried out in different time frames - most often the funds are allocated at the end of the year, leaving only a few months for the implementation of projects. A negative characteristic is also the presentation of projects based on the implementation of one or a series of events, and rarely - integrated programs. The amount of funding may vary, or it even happens that the competition took place, and the funds may be partially funded or not received at all by customers and project implementers.

It is noted that the institutional aspects of SEDR project financing require particular attention, related to the conformity of projects with the objective of regional development strategies, the terms of reference for plans for their implementation, as well as lobbying not for development projects, but for «projects supporting current activities».

The research results will be useful to representatives of legislative and executive authorities making decisions on the application of the above-mentioned project financing tools. The generalized provisions should have been taken into account when working with expert commissions on the selection of projects, working groups on strategic planning for the development of territories, etc.

The settlement of many of these problematic aspects is already being adjusted both at the state and regional levels. At the same time, there are still many unresolved issues that are the subject of further research by the authors.

\section{References}

1. Shevchenko, O. V. (2018). Zabezpechennia efektyonosti finansuvannia rozvytku rehioniv ta hromad v umovakh detsentralizatsii vlady. Available at: https://niss.gov.ua/doslidzhennya/ regionalniy-rozvitok/zabezpechennya-efektivnosti-finansuvannya-rozvitku-regioniv-ta Last accessed: 11.11.2019

2. Mamonova, V. V., Torhalo, T. O. (2016). Udoskonalennia mekhanizmiv proektuvannia rehionalnoho rozvytku v Ukraini: tekhnolohii derzhavnoho upravlinnia. Available at: http://www.dridu.dp.ua/ zbirnik/2016-01(15)/17.pdf

3. Tkach, A. A. (2005). Instytutsionalni osnovy rynkovoi infrastruktury. Kyiv: NAN Ukrainy, Obiedn. in-t ekonomiky, 295.

4. Maiorova, T. V., Kuziak, D. O. (2011). Teoretychni aspekty vyznachennia poniattia «proektne finansuvannia». Naukovyi visnyk NLTU Ukrainy, 21.14, 259-266. Available at: https:// nv.nltu.edu.ua/Archive/2011/21_14/259_Maj.pdf

5. Ieskomb, E. R. (2008). Principi proektnogo finansuvannia. Moscow; Saint-Peterburg: Vershina, 481.

6. Cordella, T., Dell'Ariccia, G. (2003). Budget Support Versus Project Aid. IMF Working Paper No. 03/88. doi: http://dx.doi.org/ 10.2139 /ssrn.408600

7. Jelovac, I., Vandeninden, F. (2008). How Should Donors Give Foreign Aid? Project Aid Versus Budget Support. GATE Working Paper No. 08-13. doi: http://dx.doi.org/10.2139/ssrn.1139811

8. Kuznetsov, I. (2018). Project-Based Approach in Managing Socio-Economic Development of the Region. Territorial Development Issues, 4 (44). doi: http://doi.org/10.15838/tdi.2018.4.44.2

9. Ngiam, K. J. (2003), 10. Regional Financial Integration in Southeast Asia. Financing Southeast Asia's Economic Development. Singapore: ISEAS-Yusof Ishak Institute Singapore, 281-314. doi: http://doi.org/10.1355/9789812306128-014

10. Stoianets, N. V. (2015). Metodolohichni aspekty sotsialnoekonomichnoho rozvytku rehionu. Naukovyi visnyk Mukachivskoho derzhavnoho universytetu, 2 (4 (2)), 208-213. Available at: https://msu.edu.ua/visn/wp-content/uploads/2015/ 12/2-4-2-2015-37.pdf Last accessed: 11.11.2019

11. Kropelnytska, S. O. Osoblyvosti pidhotovky $i$ finansuvannia proektiv rehionalnoho rozoytku. Available at: http://agentyzmin. pnu.edu.ua/ua/consaltings/osoblyvosti\%20pidhotovky\%20i\%20 finansuvannia\%20proektiv\%20rehionalnoho\%20rozvytku Last accessed: 11.11.2019

12. Prezydent pidpysav zakon pro Derzhavnyi biudzhet Ukrainy na 2020 rik (2019). Available at: https://www.president.gov.ua/news/ prezident-pidpisav-zakon-pro-derzhavnij-byudzhet-ukrayinina-58837 Last accessed: 11.12.2019 
13. Kropelnytska, S. O. (2016). Suchasni tendentsii, problemy ta perspektyvy uchasti proektiv rozvytku terytorii u konkursi na finansuvannia z DFRR. Aktualni problemy rozoytku ekonomiky rehionu, 12 (1), 37-44

14. Hrupa radnykiv pidhotuvala «Zvit pro rezultaty monitorynhu proektiv DFRR u 2015-2018 rr.» Available at: http://rdpa.regionet.org.ua/ article?id=352:sfrd-monitoring-2019 Last accessed: 19.11.2019

15. Khinotska, N. Derzhavne finansuvannia hromadskykh orhanizatsii: holovni zminy u pershii polovyni 2019 roku. Available at: https:// euprostir.org.ua/stories/142754 Last accessed: 22.12 .2019

16. Pro dobrovilne obiednannia terytorilnykh hromad (2015). Zakon Ukrainy No. 157-VIII. 05.02.2015. Available at: https:// zakon.rada.gov.ua/laws/main/157-VIII

17. Sektoralna pidtrymka YeS. Ofitsiinyi sait Departamentu z pidoyshchennia konkurentospromozhnosti rehionu Kharkivskoi oblasti. Available at: http://www.compet.kh.gov.ua/ukr/granti-ta-programi/ sektoralna-pidtrymka-yes Last accessed: 22.12.2019

18. Prohrama pidtrymky sektoralnoi polityky - Pidtrymka rehionalnoi polityky Ukrainy. Available at: https://sectoral.minregion.gov.ua/ ua Last accessed: 22.12.2019

19. Pro zasady derzhavnoi rehionalnoi polityky (2015). Zakon Ukrainy No. 157-VIII. 05.02.2015. Available at: https://zakon.rada.gov.ua/ laws/show/156-19 Last accessed: 22.12.2019
20. Propozytsii shchodo rozpodilu u 2018 rotsi biudzhetnykh koshtiv za proektamy rehionalnoho rozvytku, yaki mozhut realizovuvatysia za rakhunok koshtiv, otrymanykh vid Yevropeiskoho Soiuzu u ramkakh oykonannia Uhody pro finansuvannia Prohramy pidtrymky sektoralnoi polityky - Pidtrymka rehionalnoi polityky Ukrainy, shcho proishly konkursnyi vidbir (2018). Rozporiadzhennia Kabinetu Ministriv Ukrainy No. 569-r. 22.08.2018. Available at: https://zakon.rada.gov.ua/laws/show/569-2018-\%D1\%80 Last accessed: 22.12 .2019

21. Kropelnytska, S. O. (2016). Sektoralna biudzhetna pidtrymka YeS rehionalnoho rozvytku v Ukraini. Ekonomika, nauka, osvita: intehratsiia ta synerhiia. Vol. 1. Bratyslava, Kyiv: Vyd-vo «Tsentr navchalnoi literatury», 86-87.

Kropelnytska Svitlana, PhD, Associate Professor, Department of Finance, Vasyl Stefanyk Precarpathian National University, IvanoFrankivsk, Ukraine, e-mail: s.kropelnytska@ukr.net, ORCID: http:// orcid.org/0000-0003-4992-9550

Hryhoriv Olha, PhD, Associate Professor, Department of Finance Vasyl Stefanyk Precarpathian National University, Ivano-Frankivsk, Ukraine, e-mail: olga_grygoriv@ukr.net, ORCID: http://orcid.org/ 0000-0001-8945-6124 